\title{
On the Structure of Ocean Currents $(\mathbf{I})$
}

\author{
- Test Manufacture of a New Current Meter \\ and Some Experiments on the Sea-
}

\author{
by \\ T. Nan'niti \\ Meteorological Research Institute
}

(Received December 20, 1954)

\begin{abstract}
Though the author had once made a new current meter using a phototube [1] and observed many interesting facts with it already [2] [3], it is very expensive to use it.

Now the author has made another and simpler current meter which will record current speed fluctuations more minutely but directions more roughly than the former. With it he observed ocean currents very well and discusșed about them.
\end{abstract}

\section{Introduction}

In the previous papers [1] [2] [3], the author discussed somewhat the structure of ocean currents. To study the turbulence and structure of oceanic currents further, the author made a new type of current meter. Experiments on the sea have shown that minute current conditions can be observed very well and the current profiles can be seen easily by the instrument.

\section{The new current meter}

a) The principle of the method.

The current meter is composed of an underwater portion and a recorder on deck. These are connected by a three-fold rubber-covered cable of 50 meters long.

Current speeds are recorded on a paper tape in the recorder by the closing of the electric circuit in accordance with the frequency of rotation of the propeller.

A tape is rolled by an electric motor. Current directions are observed by a distribution of numbered and colored brass balls. The balls are dropped into a magnet box only when we want.

b) The details of the instrument.

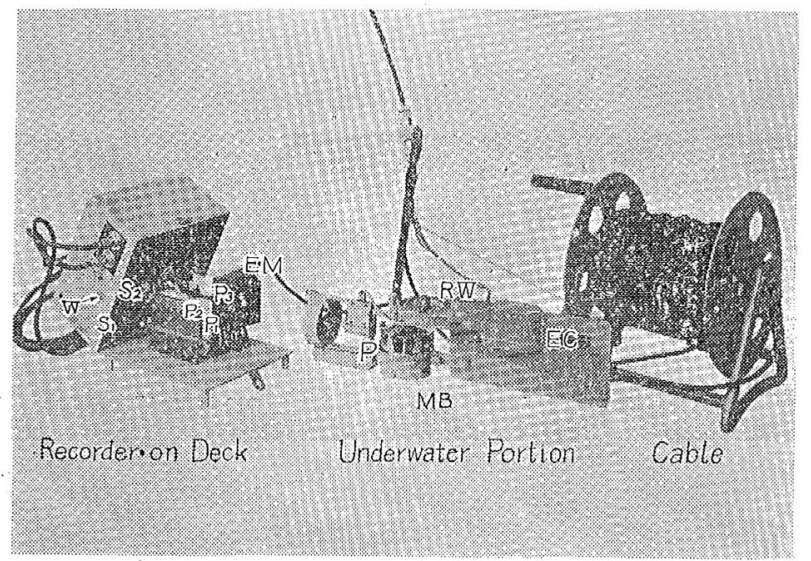

Fig. 1. The new current meter showing various components.

The current meter is shown in Fig. 1 . When water particles run $20 \mathrm{~cm}$, the 
propeller $P$ revolves one cycle and the electric circuit is closed once as the schematic circuit diagram of Fig. 2 shows. Then the recording pen $P_{1}$ in the recorder on deck will depict one signal. So we can calculated the current speeds.

To measure current directions, we turn on the switch $S_{1}$ in the recorder. Then the other electric circuit is closed and a plastic rachet wheel $R W$ in the underwater portion will be turned one pitch by the electro-magnetic force generated by the electric coil $E C$. The wheel $R W$ has 48 holes in its margin, and in every hole there are differently numbered and colored balls. So one ball will drop into the magnet box $M B$ as we turn on the switch $S_{1}$. The number of times the balls are dropped is indicated at a small window $W$ and recorded by the pen $P_{3}$ on the tape also.

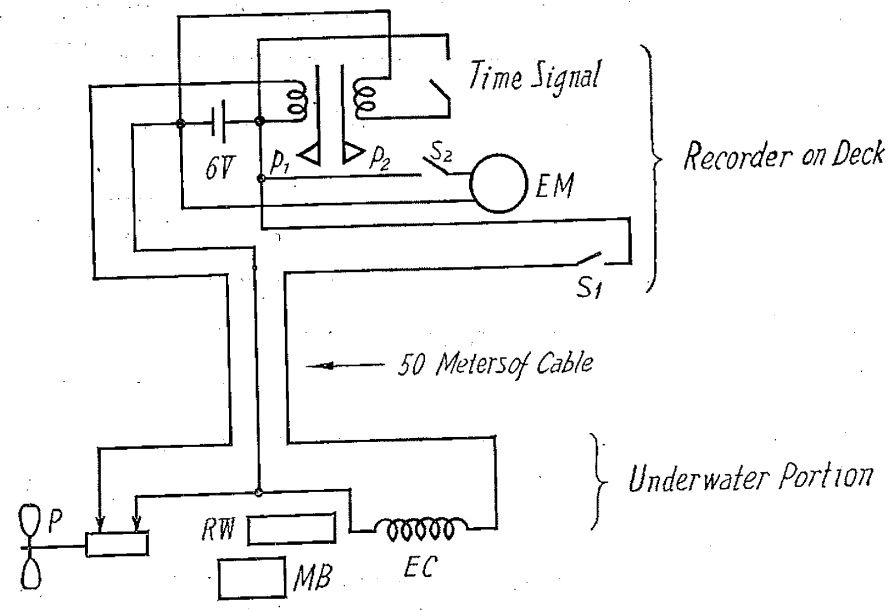

Fig. 2. Schematic circuit diagram of the instrument.

The tape is rolled with a speed of about $0.5 \mathrm{~cm} / \mathrm{sec}$ by the electric motor $E M$ when we turn on the switch $S_{2}$. The timing is marked on the chart at intervals of $30 \mathrm{sec}$. All the electric power required for the instrument is supplied by a battery of 6 volts. After one serial observation has been done we draw up the current meter, and we can find current directions by the distribution of balls.

\section{Experimental results}

The experiment was performed in Tokyo Bay on board the research ship "Ryôfû Maru" on August 16, 1954. The records are shown in Fig. 3. From the figure we can see periodic fluctuations of speed, its range being from $15 \mathrm{~cm} / \mathrm{sec}$ to $50 \mathrm{~cm} / \mathrm{sec}$, with a period of about $2.5 \mathrm{sec}$ in the layers from the surface to $3 \mathrm{~m}$. The fluctuations must have been caused by the sea with a period of $2.5 \mathrm{sec}$, for the wind speed was $5.5 \mathrm{~m} / \mathrm{sec}$ with the direction of the north at $22 \mathrm{~h}$. Putting the wave length to be $10 \mathrm{~m}$, the diminution of amplitude at $3 \mathrm{~m}$ layer is $e^{-2}=0.14$, at $5 \mathrm{~m}$ layer is $e^{-\pi}=0.04$ [4].

There is a layer of minimum speed (3

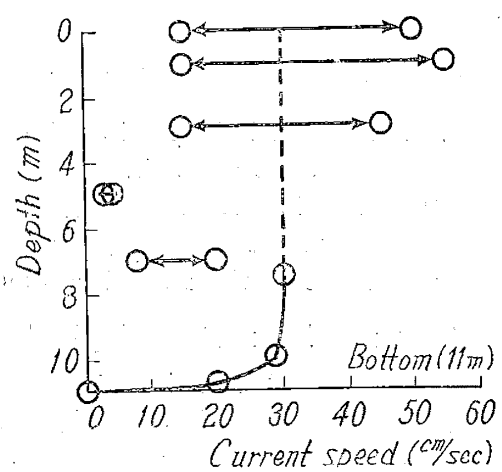

Fig. 4. Current profile from the record in Fig. 3. $4 \mathrm{~cm} / \mathrm{sec}$ ) at $5 \mathrm{~m}$ layer. The ship draws $4.5 \mathrm{~m}$ of water. And from $7.5 \mathrm{~m}$ to $10.9 \mathrm{~m}$ layer, $10 \mathrm{~cm}$ ' above the bottom, there is a steady constant speed $(20 \sim 30 \mathrm{~cm} / \mathrm{sec})$.

So the current profile is shown in Fig. 4. The ship was at anchor and did not roll. So we suspect that there was a tidal current with the speed of $30 \mathrm{~cm} / \mathrm{sec}$ and the disturbance caused by the sea was superposed on the tidal current. The 


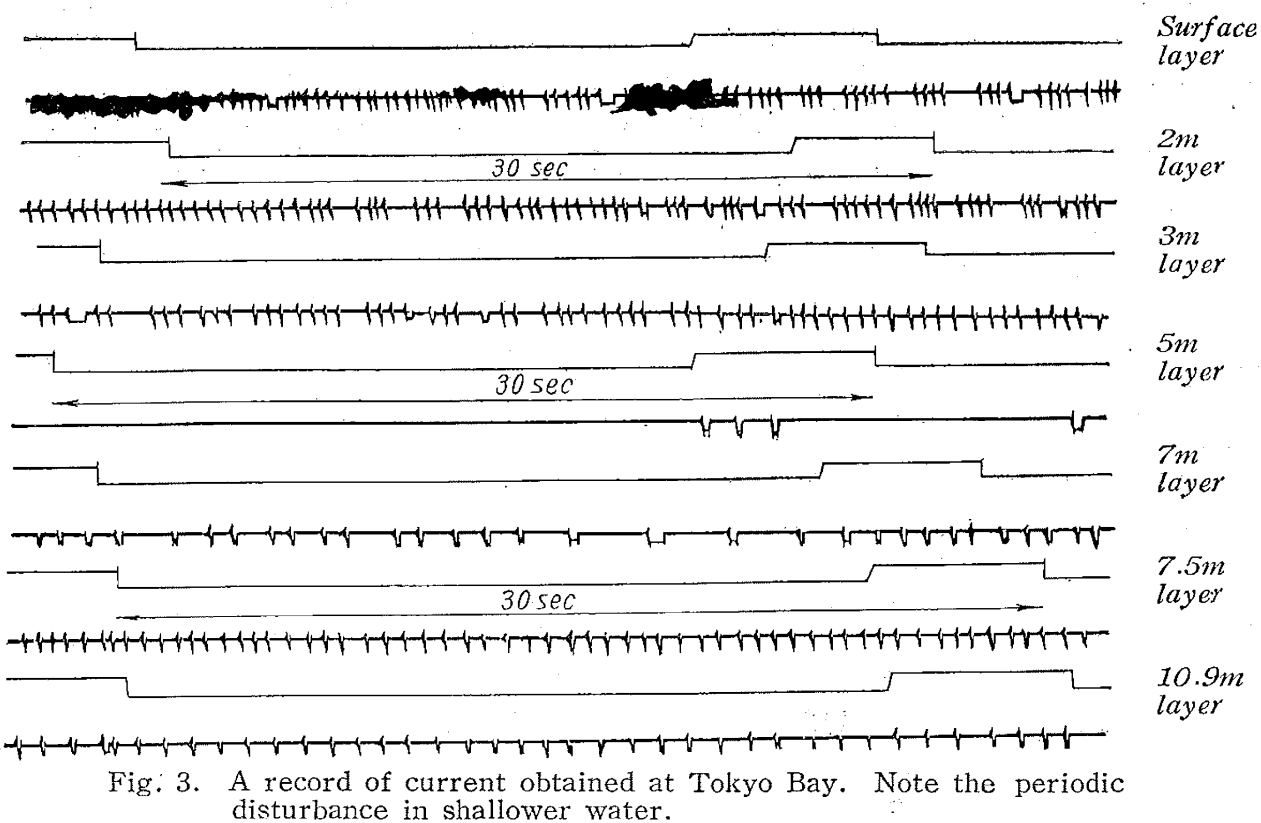

current directions were not observed owing to our carelessness.

The next experiment was performed in an open sea $\left(38^{\circ} 13^{\prime} \mathrm{N}, 142^{\circ} 58^{\prime} \mathrm{E}\right)$ at $20 \mathrm{~h}$ $30 \mathrm{~m}$ on November 19, 1945. The record is shown in Fig. 5. It shows that from the surface to the $20 \mathrm{~m}$ layer, which is the lowest layer we observed, there are periodic fluctuations of speed $(50 \sim 180 \mathrm{~cm} / \mathrm{sec})$ with periods of 7 to $8 \mathrm{sec}$.

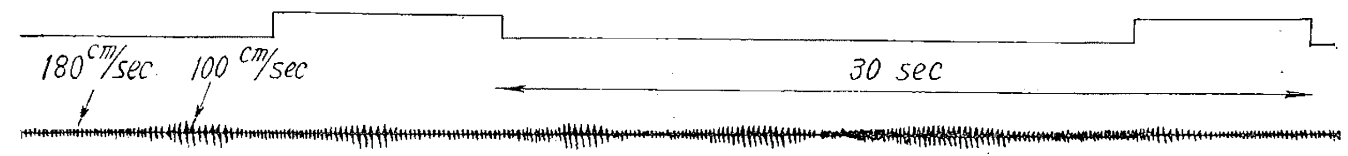

Fig. 5. A record obtained at the open sea showing the periodic fluctuation caused by the drifing of the ship. When the current speed is very large, the time interval in which the electric circuit is being closed becomes so short that the electric current is switched off before the recording pen is sufficiently pulled by the electric coil, according the amplitude of the record becomes small.

The marine-meteorological data are as follows:

Wind ESE $16.3 \mathrm{~m} / \mathrm{sec}$. Sea ESE 5 (on Beaufort's)

Swell SSE 3 (on Beaufort's) period $8 \mathrm{sec}$, height $2 \frac{1}{4} \mathrm{~m}$.

The ship "Ryôfû Maru” (1200 tons) was drifting. The observed current speeds in each layer, from the top to the $20 \mathrm{~m}$ layer, fluctuate from $50 \mathrm{~cm} / \mathrm{sec}$ to $180 \mathrm{~cm} / \mathrm{sec}$ at periods of 7 to $8 \mathrm{sec}$, with the directions of $320^{\circ}$ to $340^{\circ}$. The directions and periods of the current and wind are coincident with each other. So the obtained record must be the resultant of the drifting speed of the ship and the ocean current. Most of the resultant speed may be caused by the drifting of the current meter. So the drifting coefficient of the ship by the wind is about $1 / 16 \sim 3 / 16$ $[\mathrm{knot} / \mathrm{m} / \mathrm{sec}]$. 
The third experiment was done at $39^{\circ} 38^{\prime} \mathrm{N}, 143^{\circ} 32^{\prime} \mathrm{E}$. The marine-meteorological data at $11 \mathrm{~h}$ on November 24 are as follows:

$$
\begin{aligned}
& \text { Wind S } 11.5 \mathrm{~m} / \mathrm{sec} \text {, Sea S } 3 \text { (on Beaufort's) } \\
& \text { Swell } \mathrm{S} 1 \text { (on Beaufort's) period } 9 \mathrm{sec} \text {, height } 1.0 \mathrm{~m} \text {. }
\end{aligned}
$$

The observed data by the current meter are as follows :

\begin{tabular}{c|c|c|c}
\hline Depth $(\mathrm{m})$ & Speed $(\mathrm{cm} / \mathrm{sec})$ & Direction & $\begin{array}{c}\text { Period of fluctuations } \\
\text { (sec) }\end{array}$ \\
\hline 5 & $80 \sim 100$ & $191^{\circ}$ & 10 \\
10 & $70 \sim 90$ & $192^{\circ}$ & 10 \\
20 & $75 \sim 100$ & $226^{\circ}$ & 9.8 \\
30 & $55 \sim 90$ & $250^{\circ}$ & 9.5 \\
\hline
\end{tabular}

But the periodic fluctuations can be slightly seen.

Assuming the drifting speed of the ship by the wind to be $12 / 16=0.75$ knots: to the north, then the ocean current ought to be as follows :

\begin{tabular}{c|c|c}
\hline Depth $(\mathrm{m})$ & Speed $(\mathrm{cm} / \mathrm{sec})$ & Ditection \\
\hline 5 & 127 & $188^{\circ}$ \\
10 & 118 & $189^{\circ}$ \\
20 & 120 & $213^{\circ}$ \\
30 & 95 & $228^{\circ}$ \\
\hline
\end{tabular}

The current speed slightly decreases downwards and the current direction changes from SSW to SW.

\section{Conclusion}

The author made a new current meter and he could observe ocean currents successfully.

It recorded periodic fluctuations of speed caused by the wave and the drifting of the research ship. It is a very useful instruments enabling us to observe currents easily and to find the actual underwater speed fluctuations and profile immediately.

Further observation will be done about periodic disturbances or irregular fluctuations of ocean currents by this instrument, and the result will be analyzed providing automatic means.

Acknowledgements-The author expresses his hearty thanks to Mr. M. YAsur and the members of the Oceanographical Section, Central Meteorological Observatory, for their help during the observation. His thanks are also due to Mr. M. Iwamrya, of Turumi Seiki Co., for the construction of the instrument.

The experiment was made by a grant in 1954 from the Special Committee on Marine Resources in the UNESCO Committee of Science Council of Japan. 


\section{References}

[1] NAN'NIT, T. 1953: A Current Meter Using a Phototube (I). Pap. Met. Geophys. 3, p. 286.

[2] NaN'Niti, T. 1953: A Current Meter Using a Phototube (II). Pap. Met. Geophys. 4, p. 66.

[2] Nan'nitr, T. 1954: A Current Meter Using a Phototube (III). Pap. Met. Geophys. 5, p. 54 .

[4] LAмв, H. 1932: Hydrodynamics. Cambridge at the University Press, 6th Edition p. 365.

Errata to "A Current Meter Using a Phototube"

\begin{tabular}{|c|c|c|c|c|}
\hline Volume & Page & Line & For & Read \\
\hline \multirow[t]{2}{*}{3} & 294 & & Fig. 10 & Fig. 11 \\
\hline & $\prime \prime$ & & Fig. 11 & Fig. 12 \\
\hline \multirow[t]{10}{*}{5} & 57 & 13 & has & had \\
\hline & 60 & equation (11) & $(-1)^{m=1}$ & $(-1)^{n-1}$ \\
\hline & 00 & equation (II) & $2 m-1$ & $2 m-1$ \\
\hline & $" \prime$ & 18 & value & values \\
\hline & " & Fig. $8(a)$ & $K=155$ & $K=77.5$ \\
\hline & $\prime \prime$ & Fig. $8(\mathrm{~b})$ & $\mathrm{K}=77.5$ & $K=155$ \\
\hline & 62 & Fig. 12 & (a) direction & (a) directions \\
\hline & 63 & Fig. 13 & $10 \mathrm{~cm}$ & $10 \mathrm{~m}$ \\
\hline & $" \prime$ & 17 & $u^{2 \prime} \sim 4 \overline{73}$ & $\overline{u^{\prime 2}} \sim 4.73$ \\
\hline & $"$ & $17 \sim 18$ & $\begin{array}{l}\cdots K \sim 269 \text { c.g.s. So we } \\
\text { Furthermore } . .9 .3 \times 10^{3} .\end{array}$ & $\begin{array}{l}\ldots \mathrm{K} \sim 269 \text { c.g.s. Furthermore } \\
\ldots \ldots \ldots \ldots .9 .3 \times 10^{3} . \quad \text { So we }\end{array}$ \\
\hline
\end{tabular}

The Gothic numerals in the Column "LINE" give ones from the bottom. 